\title{
Spectrofluorimetric Determination of Nanogram Sulfide by Using Copper(II) and 2-(o-Hydroxyphenyl)benzoxazole
}

\author{
Yeong-Dae Hong, Kazuhisa Yamaya and Minoru Yoshida \\ Department of Chemistry, Faculty of Science, Tokyo Institute of Technology, \\ Ookayama, Meguro, Tokyo 152
}

\begin{abstract}
A spectrofluorimetric method for the microdetermination of sulfide was established. This will eventually be applied to silicate rock analysis. An excess amount of $\mathrm{Cu}^{2+}$ is added to precipitate copper(II) sulfide with sulfide ion. The remaining $\mathrm{Cu}^{2+}$ forms a chelate with 2-(o-hydroxyphenyl)benzoxazole (HPB) and quenches the fluorescence of HPB. The amount of sulfide is determined by measuring the fluorescence of the remaining HPB. The optimum reaction conditions, in which all the concerned reactions proceed stoichiometrically, were examined. By the proposed method, 5-640 ng sulfide can be determined with a relative standard deviation of $1.1 . \%$ at $250 \mathrm{ng} \mathrm{S} 2-$ level.
\end{abstract}

Keywords Sulfide determination, spectrofluorimetry, 2-(o-hydroxyphenyl)benzoxazole-copper(II) complex

The sulfur contents of igneous rocks have been usually described to be hundreds $\mu \mathrm{g} \mathrm{g}^{-1}$, for example, an average value ${ }^{1}$ was given as $310 \mu \mathrm{g} \mathrm{g}^{-1}$. However, Arikawa et al. ${ }^{2}$ found that Japanese volcanic rocks have distinctly lower sulfur contents. There are, indeed, a considerable number of samples containing less sulfur than the lower limit of determination for their ${ }^{2}$ and other conventional methods $\left(10 \mu \mathrm{g} \mathrm{g}^{-1} \mathrm{~S}\right)$. Ueda et al. ${ }^{3}$ confirmed the results of Arikawa et al. and suggested that the lower sulfur contents of igneous rocks might be characteristic of the island arcs. They used a gas-volumetric method ${ }^{4}$ which required up to 10 $g$ rock samples containing 1 to $10 \mu \mathrm{g} \mathrm{g}^{-1} \mathrm{~S}$ and the results exhibited relatively large errors. Therefore, we need a new and accurate method for the determination of sulfur less than $10 \mu \mathrm{g} \mathrm{g}^{-1}$ in rocks using $0.1 \mathrm{~g}$ samples.

Both of the above-mentioned authors ${ }^{2,4}$ extracted sulfur from rock samples as hydrogen sulfide by heating with a tin(II)-strong phosphoric acid reagent developed by Kiba et al..$^{5}$ The excellent decomposing ability of this reagent has been demonstrated by many investigators; it is also useful for the separation of sulfur from silicate rocks. The present study aims at the establishment of a more sensitive method for the determination of sulfide in solution at levels as low as $10 \mathrm{ng}$ after the separation. For the microdetermination of sulfide ion, fluorimetric methods have very high sensitivities. Mercuriofluorescenates ${ }^{6-8}$, 2,2'-pyridylbenzimidazole ${ }^{9}$ and 2-(o-hydroxyphenyl)benzoxazole (HPB) ${ }^{10}$ have been proposed as fluorescent reagents for the determination of sulfide. The HPB-method was selected for the present work after some preliminary investigation.

HPB forms water-insoluble chelates with various bivalent metal ions ${ }^{11,12}$ and has been applied for the gravimetric and volumetric determination of cadmium, copper, zinc and others. ${ }^{13-16}$ HPB has fluorescent properties and was used as a luminescent reagent for the determination of cadmium ${ }^{17}$ and copper. ${ }^{18}$ But, these methods are too insensitive for a fluorimetric method.

Vernon et al. ${ }^{10}$ devised a fluorimetric method for the determination of sulfide in the range of $0.1-10 \mu \mathrm{g} / 100$ $\mathrm{ml}$ (final volume). A known excess amount of $\mathrm{Cu}^{2+}$ solution is added to a sulfide sample solution to form copper(II) sulfide, and then a known excess amount of HPB solution is added. The remaining $\mathrm{Cu}^{2+}$ in solution forms the chelate and thereby attenuates the fluorescence of HPB. The amount of sulfide is determined indirectly by measuring the fluorescence intensity of the remaining HPB. Their report ${ }^{10}$ is, however, too brief to allow one to evaluate the method properly and the reported sensitivity is not satisfactory for the present purpose. In the present paper, the conditions for the reactions among sulfide, $\mathrm{Cu}^{2+}$ and HPB in a concentration region lower than that described previously are examined in detail to develop a more sensitive and practical method.

\section{Experimental}

\section{Apparatus}

A JASCO model FP-550 spectrofluorimeter with a $10-\mathrm{mm} \times 10-\mathrm{mm}$ quartz cell and a circulating ther- 
mostatic cell-holder was used for the fluorescence measurements. The scale of the relative intensity of the fluorescence was normalized to be 100 for $1 \mu \mathrm{g} \mathrm{ml}^{-1}$ quinine solution in $0.05 \mathrm{M} \mathrm{H}_{2} \mathrm{SO}_{4}$, to allow stoichiometric examinations. Temperatures for the reaction and measurement were regulated by a Thomas model TRL-N11 thermostatic water bath. A Toa-Denpa model HM-5ES pH meter with a GST-155C combined electrode was used for the $\mathrm{pH}$ measurements. For measuring volumes less than $1 \mathrm{ml}$, an automatic micropipette Micro-varipet from Funakoshi Chemical Co., was used. Experimental glassware was first immersed in a 5\% Extran MA-02 solution, and then cleaned in $0.1 \mathrm{M}$ nitric acid, in a Sharp model UT-52 ultrasonic bath.

\section{Reagents}

Deionized-distilled water was used after being deaerated by passing nitrogen gas for $30 \mathrm{~min}$. All chemicals were of analytical grade and were used without further purification.

Standard sulfide solution. The air in the flasks used for the preparation and dilution of the sulfide solutions was replaced by nitrogen gas. A little more than $0.24 \mathrm{~g}$ of crystal grains of $\mathrm{Na}_{2} \mathrm{~S} \cdot 9 \mathrm{H}_{2} \mathrm{O}$ were weighed out and the crystal surfaces were rinsed with water. The washed crystals were quickly transferred to a $100-\mathrm{ml}$ volumetric flask and dissolved in oxygen-free water. After the addition of $5 \mathrm{ml}$ of $10 \mathrm{M} \mathrm{NaOH}$ solution, the mixture was made up to $100 \mathrm{ml}$. The solution was allow to stand for a few minutes to precipitate any sulfides of heavy metal contaminants that might be present and, was then standardized by iodometry (about $\left.1 \times 10^{-2} \mathrm{M}\right)$. A working standard solution (1X $10^{-5} \mathrm{M}$ ) was prepared by two-step dilution with caution to avoid air-oxidation, and was used within $20 \mathrm{~min}$ after the standardization.

$H P B$ solution. Exactly $0.0211 \mathrm{~g}$ of 2-(o-hydroxyphenyl)benzoxazole was dissolved in ethanol and diluted to the mark in a $100-\mathrm{ml}$ volumetric flask. This solution $\left(10^{-3} \mathrm{M}\right)$ was stored in a dark and cool place. The working solution $\left(5 \times 10^{-5} \mathrm{M}\right)$ was prepared by suitable dilution with ethanol.

Copper(In) solution. Exactly $0.2497 \mathrm{~g}$ of $\mathrm{CuSO}_{4}$. $5 \mathrm{H}_{2} \mathrm{O}$ was dissolved and made up to 11 in a volumetric flask with $0.25 \mathrm{M} \mathrm{H}_{2} \mathrm{SO}_{4}\left(10^{-3} \mathrm{M} \mathrm{Cu}^{2+}\right)$. The working solution $\left(5 \times 10^{-5} \mathrm{M}\right)$ was prepared by suitable dilution with $0.25 \mathrm{M} \mathrm{H}_{2} \mathrm{SO}_{4}$.

Buffer solutions. The buffer solution of $\mathrm{pH} 12.0$ was prepared by mixing $10.0 \mathrm{ml}$ of $1 \mathrm{M}$ disodium hydrogen phosphate solution with $6.7 \mathrm{ml}$ of $1 \mathrm{M}$ sodium hydroxide solution and diluting to $100 \mathrm{ml}$. Other buffer solutions required for the examination of the effect of $\mathrm{pH}$ were appropriately prepared from $1 \mathrm{M}$ hydrochloric acid, $1 \mathrm{M}$ sodium acetate, $0.2 \mathrm{M}$ acetic acid, $0.2 \mathrm{M}$ sodium dihydrogen phosphate, $0.2 \mathrm{M}$ sodium hydroxide and $0.2 \mathrm{M}$ sodium tetraborate.

\section{Recommended procedure}

First, replace the air in a $25-\mathrm{ml}$ amber volumetric flask by nitrogen gas. Place $0.40 \mathrm{ml}$ of the $5 \times 10^{-5} \mathrm{M}$ copper(II) solution in the flask and dilute to about 10 $\mathrm{ml}$ using oxygen-free water. Transfer up to $10 \mathrm{ml}$ of a sample solution containing less than $600 \mathrm{ng} \mathrm{S}{ }^{2-}$ to the flask and mix well. Add $1.00 \mathrm{ml}$ of the HPB solution $\left(5 \times 10^{-5} \mathrm{M}\right)$ to the flask, mix well and allow to stand for $2 \mathrm{~min}$. Finally, add $1.0 \mathrm{ml}$ of the $\mathrm{pH} \mathrm{12-buffer} \mathrm{solution}$ and dilute to the mark. Shake the flask vigorously by hand, and then allow the mixture to stand for $\mathbf{4 0} \mathrm{min}$ at $40 \pm 0.1^{\circ} \mathrm{C}$. Measure the fluorescence intensity of the solution at $359 \mathrm{~nm}$ for excitation and $434 \mathrm{~nm}$ for emission at $40 \pm 0.1^{\circ} \mathrm{C}$. Determine the sulfide concentration from the calibration graph.

\section{Results and Discussion}

\section{Fluorescent property of $\mathrm{HPB}$}

The intense blue fluorescence of HPB appears as the $\mathrm{pH}$ increases above 7, increases steadly up to $\mathrm{pH} \mathbf{1 1 . 2}$ and remains constant in the higher $\mathrm{pH}$ region (Fig. 1). This indicates that it is the anionic form of HPB that fluoresces. The conditional $\mathrm{p} K_{\mathrm{a}}$ of HPB in aqueous (4\% ethanol) solution (ionic strength: $c a .0 .02,20^{\circ} \mathrm{C}$ ) can be determined as $\mathbf{1 0 . 0}$ from the curve in Fig. 1. The reported values of $\mathrm{p} K_{\mathrm{a}}$ in $50 \%$ ethanol or $50 \%$ dioxane media are from 11.1 to 11.6.12,19 The difference between the present and the reported values may be due to the different solvent used (see the later section on the effect of solvents).

The uncorrected excitation and emission spectra of HPB were examined using $4.74 \times 10^{-6} \mathrm{M}$ HPB aqueous solution (4\% ethanol) at $\mathrm{pH} 12$. The excitation and emission maxima were found to occur at 359 and 434

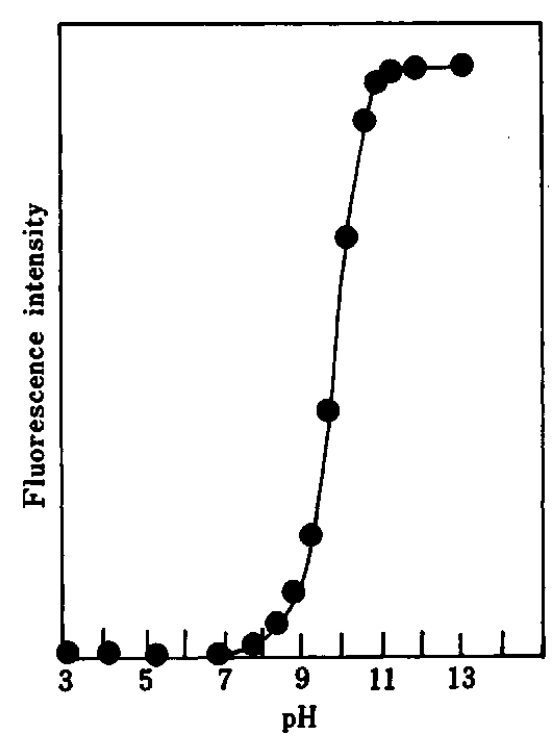

Fig. 1 Effect of $\mathrm{pH}$ on the fluorescence intensity of HPB (4X $\left.10^{-6} \mathrm{M}\right)$. 
$\mathrm{nm}$, respectively. The fluorescence intensities were measured at these wavelengths.

The fluorescence intensity of HPB decreases with an increase of temperature and thus it is necessary to measure the fluorescence at a constant temperature for accurate work. When an alkaline aqueous solution of HPB was exposed to diffused day-light, the fluorescence intensity decreased appreciably. Amber flasks were therefore used; no decrease of fluorescence was observed over $\mathbf{5} \mathrm{h}$. The ethanol solution of HPB was, however, stable during prolonged storage.

The reactions that constitute the basis of the method are presumed to be as follows:

$$
\begin{aligned}
& \mathrm{S}^{2-}+\mathrm{Cu}^{2+}=\mathrm{CuS} \\
& \mathrm{Cu}^{2+}+2 \mathrm{HPB}^{-}=\mathrm{Cu}(\mathrm{HPB})_{2} .
\end{aligned}
$$

If the reactions occur stoichiometrically, the amount of HPB correspoding to $10 \mathrm{ng}$ of sulfur is calculated to be $132 \mathrm{ng}$. For a total volume of $25 \mathrm{ml}$, the HPB con-

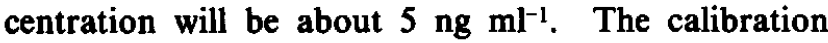
graph of HPB shows a reproducible linear relationship in the concentration range of 0 to $10 \mathrm{ng} \mathrm{ml}^{-1}$. Then, the sensitivity of HPB as a fluorescent reagent is sufficient to achieve the desired purpose.

\section{Formation of copper(II)-HPB complex}

For a suitable method, appreciable and reproducible quenching due to the copperr(II)-HPB complex formation must take place in the $10^{-7}-10^{-5} \mathrm{M}$ range. The fluorescence intensities of solutions containing $1.0 \times 10^{-7} \mathrm{~mol} \mathrm{HPB}$ and $4.0 \times 10^{-8} \mathrm{~mol} \mathrm{Cu}^{2+}$ in $25 \mathrm{ml}$ with pH values of $11-13$ were measured. The results are

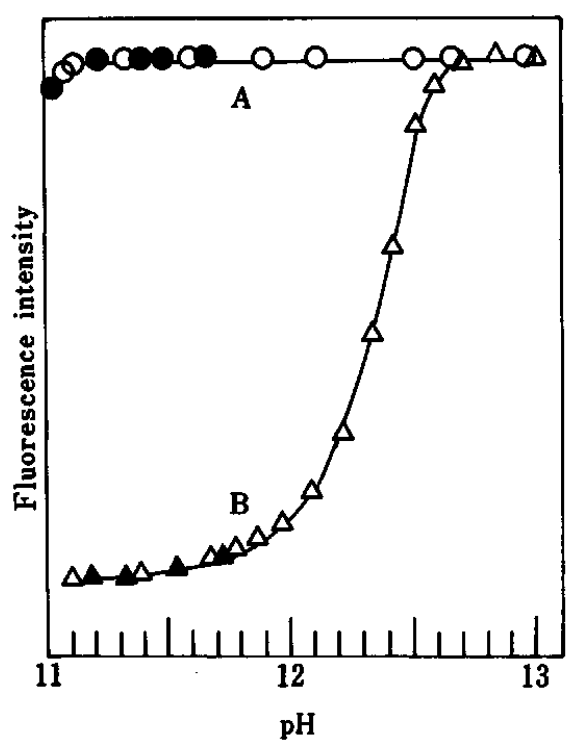

Fig. 2 Effect of $\mathrm{pH}$ on the fluorescence intensity of $\mathrm{HPB}$ and copper(II)-HPB system. A, $(O, O) 4 \times 10^{-6}$ M HPB; B, $(\triangle$, A) $4 \times 10^{-6} \mathrm{M} \mathrm{HPB}+1.6 \times 10^{-6} \mathrm{M} \mathrm{Cu} \mathrm{Cu}^{2+}$; Open marks $(\mathrm{O}, \Delta)$, $\mathrm{pH}$ is adjusted by $\mathrm{NaOH}$; Closed marks $(\mathrm{O}, \mathrm{\Delta}), \mathrm{pH}$ is adjusted by $\mathrm{Na}_{2} \mathrm{HPO}_{4}-\mathrm{NaOH}$ buffer solutions. shown in Fig. 2, together with those obtained with HPB alone. In the pH range below 11.6, the quenching took place almost quantitatively, as calculated from the calibration line of HPB and the reaction-stoichiometry. The fluorescence intensity increases as $\mathrm{pH}$ rises, and above 12.7 it coincides with that of HPB alone; this may be caused by the formation of stable hydroxocomplexes of copper(II). The formation constant of $\mathrm{Cu}(\mathrm{HPB})_{2}$ can be roughly estimated to be $10^{30}$ from the curve $B$ in Fig. 2, on the assumption that $\mathrm{Cu}(\mathrm{HPB})_{2}$ exists as a solid phase and that $\mathrm{Cu}(\mathrm{OH})_{4^{2-}}$ is the predominant copper(II)-species in the solution around pH 12. ${ }^{20}$ The optimum pH range for the analytical procedures is between 11.2 and 11.6 and is so narrow that adjustment of $\mathrm{pH}$ by $\mathrm{NaOH}$ solution as described by Vernon et al.10 is very difficult. The use of buffer solutions was, therefore, examined. As is also seen from Fig. 2, the use of phosphate buffer solutions did not affect the fluorescence intensities of the HPB and copper(II)-HPB systems at all as compared with the results obtained by using $\mathrm{NaOH}$. In the recommended procedure, the $\mathrm{pH}$ of the solution is adjusted within $11.3 \pm 0.1$ by the addition of $1 \mathrm{ml}$ of the $\mathrm{pH} 12$ buffer solution $\left(\mathrm{NaOH}-\mathrm{Na}_{2} \mathrm{HPO}_{4}\right)$ in co-operation with the sulfuric acid in the copper(II) solution.

Temperature has a greater influence on the reaction between copper(II) and HPB than on the fluorescence intensity of HPB. The determination of the composition of the complex was attempted by the molar ratio method. The $\mathrm{HPB} / \mathrm{Cu}$ ratios obtained at room temperatures $\left(20-25^{\circ} \mathrm{C}\right)$ were distributed between 2.2 and 2.6, which are distinctly higher than the value of 2.0 reported by gravimetric studies. ${ }^{12,15}$ The composition: $\mathrm{Cu}(\mathrm{HPB})_{2}$ is considered to be reasonable based on the coordination number of $\mathrm{Cu}^{2+}$ and the structure of HPB. The $\mathrm{Cu}-\mathrm{HPB}$ precipitate was formed and/or digested at higher temperatures in the gravimetric studies cited above ${ }^{12,15}$. Then, the effect of digestion on the apparent composition of the complex was investigated by changing the temperature from 10 to $60^{\circ} \mathrm{C}$ (Fig. 3). The molar ratio $\mathrm{HPB} / \mathrm{Cu}$ was found to be 2.0 above $40^{\circ} \mathrm{C}$, but to have larger and nonintegral values at lower temperatures. The excess consumption of HPB observed at the low temperatures may have resulted from coprecipitation phenomena. To secure the reproducible and stoichiometric relationships, $40^{\circ} \mathrm{C}$ was adopted as the standing temperature.

The effects of standing time and of order of addition of the reagents on the complex formation were also studied. The fluorescence intensities of the solutions immediately after the preparation were lower than would be expected from the stoichiometry, and they gradually increased on standing. The intensity became constant at the expected value after about $30 \mathrm{~min}$ at $40^{\circ} \mathrm{C}$ when $\mathrm{HPB}$ was added to $\mathrm{Cu}^{2+}$ prior to addition of the buffer solution. On the other hand, it did not reach the expected value even after $2 \mathrm{~h}$ if the addition order was reversed. Therefore, the reagents should be added in the order: copper(II), HPB and buffer; then 
the solution should be allowed to stand for $\mathbf{4 0} \mathrm{min}$ in the thermostatic bath controlled at $40 \pm 0.1^{\circ} \mathrm{C}$.

Under the operating conditions established above, we can determine $0.01-1.3 \mu \mathrm{g}$ of $\mathrm{Cu}^{2+}$ fluorimetrically. The calibration graph gives a linear relation up to $8 \times 10^{-7} \mathrm{M} \mathrm{Cu}^{2+}(\mathrm{HPB} / \mathrm{Cu}=2.5)$ (Fig. 4). The graph is extended over the determination limit showing a molar ratio plot for the complex.

\section{Determination of sulfide}

As is well known, the solutions of sulfides are very unstable, especially in low concentrations. In addition to the usual instructions, that is, deaeration of water and addition of alkali, the air in all the vessels was replaced by nitrogen gas, especially when $10^{-5} \mathrm{M}$ sulfide solutions were treated. Then, the sulfide solu-

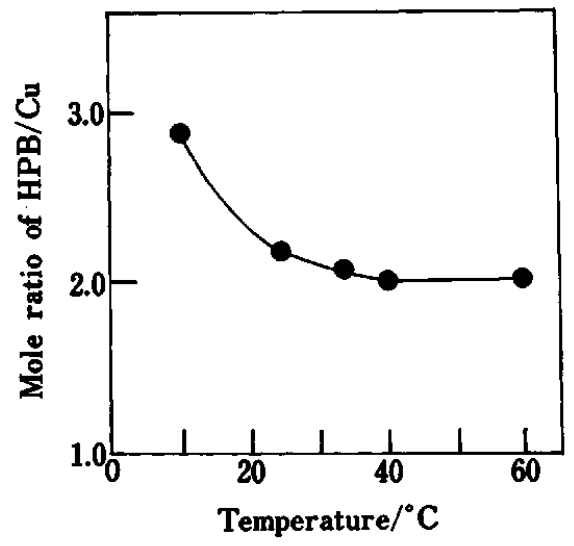

Fig. 3 Effect of digestion temperature on the apparent composition of copper(II)-HPB complex. $5 \times 10^{-5} \mathrm{M}$ HPB $1 \mathrm{ml}, 5 \times 10^{-5} \mathrm{M} \mathrm{Cu}^{2+} 0-0.8 \mathrm{ml}$; $\mathrm{pH} 11.5$; standing time: 30 $\min$.

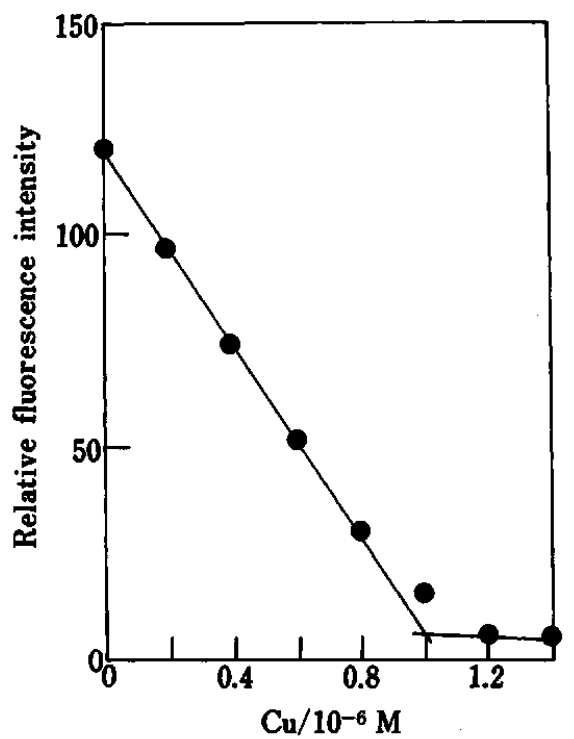

Fig. 4 Calibration curve (=molar ratio plot) of $\mathrm{Cu}^{2+}$. HPB: $2 \times 10^{-6} \mathrm{M}$; pH 11.3 ; temp.: $40^{\circ} \mathrm{C}$; standing time: $40 \mathrm{~min}$. tions were stable for $\mathbf{2 0} \mathrm{min}$ after the standardization.

The formation of copper(II) sulfide in solution is accomplished rapidly and quantitatively. But when sulfide ion was added after the formation of $\mathrm{Cu}(\mathrm{HPB})_{2}$ the substitution of sulfide for HPB did not proceed quantitatively. By combination with the results in the previous section, the order of addition of the reagents was decided as described above.

The amounts of copper(II) and HPB to be used were decided as $0.4 \mathrm{ml}$ of the $5 \times 10^{-5} \mathrm{M}$ copper(II) solution and $1 \mathrm{ml}$ of the $5 \times 10^{-5} \mathrm{M}$ HPB solution which is in excess of $\mathrm{Cu}^{2+}$. If they are added stoichiometrically, the calibration graph will curve in the low concentration part, as predicted from Fig. 4.

The calibration graph for sulfide is shown in Fig. 5, extending a little beyond the upper limit of practical use. The line in the figure is drawn according to the calculation from the reaction-stoichiometry and the calibration line of HPB. Experimental points fall exactly on the line. This indicates that all the reactions proceed quantitatively as presumed. By the proposed method, 5 to $640 \mathrm{ng}$ of sulfide in aqueous solutions can be determined. A relative standard deviation at $250 \mathrm{ng}$ sulfide level is $\pm 1.14 \%$.

\section{Effect of solvents}

The solution prepared by the recommended procedure contains $4 \%$ of ethanol added as the solvent for HPB. The effect of addition of excess ethanol or other solvents on the proposed method was examined. The maximum intensity of fluorescence of HPB increased with concentrations of solvents with the effect decreasing in the following order: dioxane >ethanol $>$ methanol>acetone. Although dioxane shows the largest intensification, the fluorescence of HPB becomes unstable in this solvent and consequently it is of no

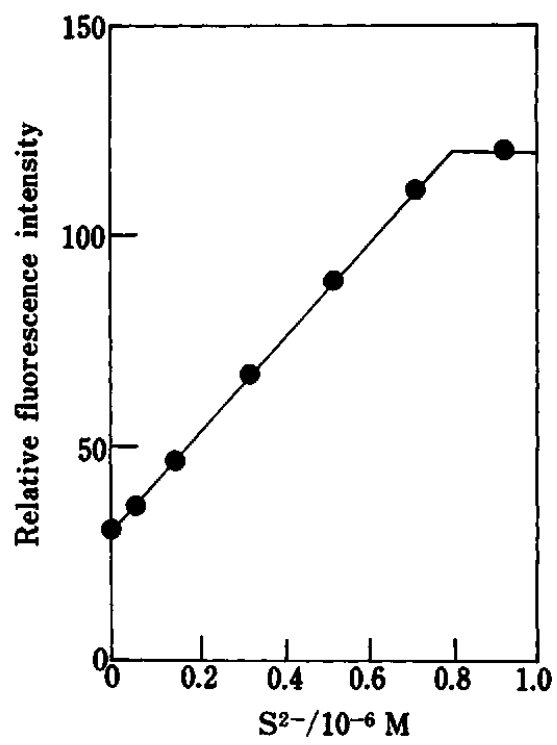

Fig. 5 Examination on the stoichiometry of the reactions (= calibration curve of $\mathrm{S}^{2-}$ ). (O) experimental values; line: calculated from the stoichiometry. 
Table 1 Effect of diverse ions ( $\mathrm{S}^{2}-$ taken : $\left.10.0 \mathrm{ng} \mathrm{ml}^{-1}\right)$

\begin{tabular}{|c|c|c|c|}
\hline Ion & Added as & $\begin{array}{l}\text { Amount } \\
\text { added/ } \\
\mu \mathrm{g} \mathrm{ml} \mathrm{m}^{-1}\end{array}$ & 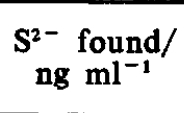 \\
\hline None & & & $10.0 \pm 0.26^{a}$ \\
\hline \multirow[t]{2}{*}{$\mathrm{Na}^{+}$} & $\mathrm{NaCl}$ & 80 & 9.6 \\
\hline & & 10 & 10.1 \\
\hline \multirow[t]{2}{*}{$\mathbf{K}^{+}$} & $\mathrm{KCl}$ & 80 & 9.6 \\
\hline & & 10 & 9.9 \\
\hline $\mathrm{Zn}^{2+}$ & $\underset{2 \mathrm{H}_{2} \mathrm{O}}{\mathrm{Zn}\left(\mathrm{CH}_{3} \mathrm{COO}\right)_{2}}$ & 80 & 9.9 \\
\hline \multirow[t]{2}{*}{$\mathrm{SO}_{4}{ }^{2-}$} & $\mathrm{Na}_{2} \mathrm{SO}_{4}$ & 80 & 9.6 \\
\hline & & 10 & 9.9 \\
\hline \multirow[t]{2}{*}{$\mathrm{SO}_{3}{ }^{2-}$} & $\mathrm{NaHSO}_{3}$ & 1 & 8.9 \\
\hline & & 0.1 & 9.6 \\
\hline $\mathrm{S}_{2} \mathrm{O}_{3}{ }^{2-}$ & $\mathrm{Na}_{2} \mathrm{~S}_{2} \mathrm{O}_{3} \cdot 5 \mathrm{H}_{2} \mathrm{O}$ & 0.01 & 11.2 \\
\hline $\mathrm{BO}_{3}{ }^{3-}$ & $\mathrm{H}_{3} \mathrm{BO}_{3}$ & 10 & 9.6 \\
\hline $\mathrm{PO}_{4}{ }^{3-}$ & $\mathrm{NaH}_{2} \mathrm{PO}_{4} \cdot 2 \mathrm{H}_{2} \mathrm{O}$ & 10 & 9.7 \\
\hline $\mathrm{NO}_{3}^{-}$ & $\mathrm{NaNO}_{3}$ & 10 & 9.6 \\
\hline \multirow[t]{2}{*}{$\mathrm{NO}_{2}^{-}$} & $\mathrm{NaNO}_{2}$ & 10 & 2.3 \\
\hline & & 0.01 & 9.9 \\
\hline $\mathrm{SCN}^{-}$ & KSCN & 0.4 & 9.9 \\
\hline $\mathrm{CN}^{-}$ & $\mathrm{KCN}$ & 0.01 & 14.1 \\
\hline $\mathbf{F}^{-}$ & $\mathrm{NaF}$ & 10 & 10.2 \\
\hline $\mathrm{Cl}^{-}$ & $\mathrm{NaCl}$ & 10 & 10.1 \\
\hline $\mathrm{Br}^{-}$ & $\mathbf{K B r}$ & 10 & 9.6 \\
\hline $\mathbf{I}^{-}$ & $\mathbf{K I}$ & 10 & 10.1 \\
\hline
\end{tabular}

a. $95 \%$ confidence interval $(n=10)$.

practical use for the present analysis.

The fluorescence intensity of HPB was almost doubled in $50 \%$ (by volume) ethanol media and was stable. But in $50 \%$ ethanol, the acid-dissociation curve of HPB was appreciably shifted to the higher $\mathrm{pH}$ side, presumably due to the lower dielectric constant of the medium. The $\mathrm{p} K_{\mathrm{a}}$ of HPB in $50 \%$ ethanol is estimated to be about 11 in agreement with reported values. ${ }^{12,19}$ On the other hand, the $\mathrm{pH}$ range where the conversion between $\mathrm{Cu}(\mathrm{HPB})_{2}$ and hydroxo-complexes of copper(II) takes place was almost unchanged. Consequently, an optimal $\mathrm{pH}$-region in which both the HPBdissociation (fluorescence appearance) and $\mathrm{Cu}(\mathrm{HPB})_{2}-$ formation (quenching) reactions proceed quantitatively could not be found. Thus, attempts to modify the method by the addition of solvents were abandoned.

\section{Effects of diverse ions}

The effects of some ions on the determination of 10 $\mathrm{ng} \mathrm{ml}{ }^{-1}$ of sulfide ion are listed in Table 1 . Thiosulfate and cyanide gave appreciably higher results due to the complex-formation with copper(II). Most heavy-metal ions and oxidizing agents (not listed in the table) also seriously affect the method, but these species are incompatible with sulfide in aqueous solutions. In any event, sulfide must be separated as hydrogen sulfide from samples of complex composition as has been conventional. to achieve the expected objective. If the sulfur in rocks is recovered completely as sulfide ion, $0.05-6 \mu \mathrm{g} \mathrm{g}^{-1} \mathrm{~S}$ may be determined by using $0.1 \mathrm{~g}$ of samples. The fact that all the reactions proceed stoichiometrically in the determination process guarantees the validity of the method and, moreover, will offer many advantages in the future attempts to separate sulfur from rock matrices. All kinds of sulfur species in rocks may be separated from most interfering components by the tin(II)-strong phosphoric acid method.,5 Possible contamination of phosphate by carry-over of the reagent-mist will offer no problem, because the tolerance of the present method for phosphate is very large.

In conclusion, the proposed method is very promising for the application to the determination of ultramicro amounts of sulfur in silicate rocks.

\section{References}

1. K. H. Wedepohl, in "Origin and Distribution of the Elements", pp. 1011 - 1013, ed. L. H. Ahrens, Pergamon, Oxford (1968).

2. Y. Arikawa, T. Ozawa and I. Iwasaki. Bumseki Kagaku, 21, 920 (1972).

3. A. Ueda and H. Sakai, Geochim. Cosmochim. Acta, 48, 1837 (1984).

4. A. Ueda and H. Sakai, Geochem. J., 17, 185 (1983).

5. T. Kiba, T. Takagi, Y. Yoshimura and I. Kishi, Bull. Chem. Soc. Jpn., 28, 641 (1955).

6. T. R. Andrew and P. N. R. Nichols, Analyst [London], 90, 367 (1965).

7. H. D. Axelrod, J. H. Cary, J. E. Bonelli and J. P. Lodge, Anal. Chem., 41, 1856 (1969).

8. S. Goda, K. Morishige, N. Yamada, M. Okatake and Y. Nishikawa, Branseki Kagaku, 35, 80 (1986).

9. L. S. Bark and A. Rixon, Analyst [London], 95, 786, (1970).

10. F. Vernon and P. Whithan, Anal. Chim. Acta, 59, 155 (1972).

11. H. Freiser, Analyst [London], 77, 830 (1952).

12. R. G. Charles and H. Freiser, Anal. Chim. Acta, 11, 1 (1954).

13. J. L. Walter and H. Freiser, Anal. Chem., 24, 984 (1952).

14. J. L. Walter and H. Freiser, Anal. Chem., 24, 1985 (1952).

15. E. E. Byrn and J. H. Robertson, Anal. Chem., 26, 1605 (1954).

16. Y. Horiuchi and T. Kawamoto, Bunseki Kagaku, 18, 329 (1969).

17. N. Evcim and L. A. Reber, Anal. Chem., 26, 936 (1954).

18. E. A. Bozhevolnov, Sb. Statei, Vses. Nauchn.-Issled. Inst. Khim. Reactivov i Osobo Chistykh Khim. Veshchestv, No 24, 24 (1961); Chem. Abstr., 57, 27h (1962)].

19. Z. Holzbecher, Collect. Czech. Chem. Comm., 24, 3915 (1959).

20. J. Kragten, "Atlas of Metal-Ligand Equilibria in Aqueous Solution", pp.222-223, Ellis Horwood-Wiley, New York (1978). 